\title{
CATCHING-UP, INFLATION DIFFERENTIALS AND CREDIT BOOMS IN A HETEROGENEOUS MONETARY UNION: SOME IMPLICATIONS FOR EMU AND NEW EU MEMBER STATES
}

\author{
RONALD MACDONALD \\ CEZARY WOJCIK \\ CESIFO WORKING PAPER NO. 1761 \\ CATEgORy 6: MONETARy POLICY AND INTERNATIONAL FinANCE \\ JULY 2006
}

An electronic version of the paper may be downloaded

- from the SSRN website:

www.SSRN.com

- from the RePEc website:

www.RePEc.org

- from the CESifo website:

www.CESifo-group.de 


\title{
CATCHING-UP, INFLATION DIFFERENTIALS AND CREDIT BOOMS IN A HETEROGENEOUS MONETARY UNION: SOME IMPLICATIONS FOR EMU AND NEW EU MEMBER STATES
}

\begin{abstract}
In this paper we propose an alternative explanation for the nature, sources and consequences of inflation rate differentials in a monetary union, such as EMU. To achieve this, we build on the new neoclassical synthesis (NNS) framework, recently advanced by Goodfriend (2002) and Goodfriend and King (2000). Based on the NNS setup, we discuss the inflationary consequences of the catching-up process in a heterogeneous monetary union. In particular, we explore the interaction between catching-up and inflation differentials and offer an interpretation of the nature of this interaction. Our discussion is in stark contrast to the conventional Balassa-Samuelson (BS) interpretation. In particular, we demonstrate that divergent inflation rates between Member States do not necessarily have to be an equilibrium phenomenon, even if the original shock comes from the supply-side of the economy. Second, we show how a centralized monetary policy may produce such divergence of individual country's inflation rates when countries differ in size and in trend productivity growth. Against this background, we additionally show how the catching may potentially lead to unsustainable credit booms in a catching-up member country. Finally, we indicate some important deficiencies of the BS model as a guide to short- and medium-run policy making analysis.
\end{abstract}

JEL Code: F3.

Keywords: inflation differentials, credit booms, new neoclassical synthesis, monetary union, EMU, Balassa-Samuelson model.

\author{
Ronald MacDonald \\ Department of Economics \\ University of Glasgow \\ Glasgow G12 8QQ \\ Scotland - United Kingdom \\ r.macdonald@socsci.gla.ac.uk
}

\author{
Cezary Wojcik \\ Warsaw School of Economics \\ Al. Niepodleglosci 164 \\ 02-554 Warsaw \\ Poland \\ cezary.wojcik@sgh.waw.pl
}

We would like to thank Marvin Goodfriend and Jacques Melitz for helpful comments and suggestions. 


\section{Introduction}

Inflation differentials between the European Union (EU) Member States participating in Economic and Monetary Union (EMU) have widened since the introduction of the single currency, the high point of the convergence process. For example, the spread between the highest and lowest inflation rate, which had been about 0.6 percentage points in January 1998, increased to around 3.4 percentage points in 2000 and reached almost 4.0 percentage points in February 2003. It stabilized thereafter and in July 2005 it stood at 3.1 percentage points. It is true that the convergence of inflation rates in the late 90 s resulted from a deliberate policy action of member states aimed at meeting the Maastricht inflation criterion in the run-up to EMU, but still the inflation differentials observed thereafter are more regionally persistent than in the US economy and higher than had been predicted by some leading commentators (see, for example, De Grauwe (1992) and Canzoneri et al (1996)). The inclusion of the EU accession countries from Central and Eastern Europe into the EU has produced a more heterogeneous grouping of countries and will presumably result in such inflation differentials and their persistence rising even further. Therefore a pertinent policy question, that both the current and future EMU members face, is: what is the nature and what are the sources and consequences of the observed divergence in inflation rates within the EMU? In particular, does this divergence represent an equilibrium adjustment of relative prices, which should not be a source of concern, or is it, rather, a sign of rising disequilibrium stimulated by the common one-size-fits-all monetary policy? If the latter interpretation is correct it may have important policy implications for the euro area.

A common explanation of the observed divergence in inflation rates within the EU draws on the Balassa-Samuelson model (see Balassa (1964), Samuelson (1964); for a formalization of the model see, for example, De Gregorio, Giovannini and Wolf, (1994) or Froot and Rogoff, (1995)). In this framework inflation differentials emanate from the supply-side during the catching-up process: with a constant nominal exchange rate, a positive shock to total factor productivity in the traded 
sector raises the average wage in the economy, and thus both the relative price of non-traded to traded goods and the inflation rate rise. In this setup, inflationary pressures are not viewed as a source of concern as they are an equilibrium, productivity-driven, phenomenon that is unlikely to have a deleterious effect on competitiveness and growth.

The above hypothesis, although widely accepted in the profession (for criticisms see for example Bergin et al. (2004) and Podkaminer (2003)), does not seem to be supported by the recent experience in the EU. For example, and as we have noted, the inflation rate spread in EMU has been continuously increasing since its inception, although trend productivity growth rates in Member States have not experienced any major change during that time and, of course, exchange rates have been irrevocably fixed. With the trend productivity growth and exchange rates constant across Member States, the Balassa-Samuelson (BS) hypothesis predicts that the inflation spread should have stayed constant, if this hypothesis were in fact the main driving force behind inflation developments in EMU. The fact that the spread has been non-constant suggests that there must be other factors at work.

In this paper we propose an alternative explanation for the nature, sources and consequences of inflation rate differentials in a heterogeneous monetary union such as the EMU. Our alternative explanation is based on the new neoclassical synthesis (NNS) framework, as proposed by Goodfriend (2002) and Goodfriend and King (2000). Our discussion is in sharp contrast to the conventional BS interpretation. In particular, we demonstrate that divergent inflation rates between Member States do not necessarily have to be an equilibrium phenomenon, even if the original shock comes from the supply-side of the economy. Second, we show how a centralized monetary policy may incite such divergence of individual country's inflation rates when countries differ in size and in trend productivity growth. Using this framework, we additionally show how it may potentially lead to unsustainable credit booms in a small catching-up member country. The issue of credit booms and boom-bust cycles has recently gained a central place in the policy and academic 
discussions regarding the full monetary integration of the new EU Member States from Eastern and Central Europe with EMU ${ }^{1}$ and in this paper we contribute to this literature by proposing a simple framework to understand the potential nature and sources of such credit booms in a monetary union with catch-up. Furthermore, we indicate some important deficiencies of the BS model as a guide for short- and medium-run policy making analysis. Additionally, we show how standard estimates of the productivity - inflation relationship can potentially produce an upward bias in the point estimates of the BS effect.

The effect we focus on here paper is essentially a demand side phenomenon, albeit one which starts from a supply side shock. The influence of demand, of both the public and private sector, on inflation and the internal price ratio has, of course, previously been highlighted in a number of papers (see for example Dornbusch (1988), Neary (1988) and Bergstrand (1991)). The latter formalizes a proposition by Linder (1961) that per capita income is likely to be the most important single determinant of the demand structure within a country. The main idea is that as a country catches up, and income rises, demand-side factors can affect the internal price ratio if preferences are nonhomothetic; usually preferences are thought to be biased in favor of the nontraded good because services are viewed as superior goods.

Our discussion of the effect of demand shocks is different to that considered previously in the literature, as it starts from a supply side shock. In particular, we focus on the role of consumption smoothing in driving inflation differentials. We also explicitly consider the case of a monetary and, in particular, a heterogeneous monetary union, which allows us to address issues relevant for stabilization policy in a monetary union, like the EMU.

It is important to stress at the outset that our approach is rather rudimentary in the sense that we take an existing model, namely the NNS, and use it to interpret inflation differentials in the context of a heterogeneous monetary union such as the EMU. While our analysis delivers, we

\footnotetext{
${ }^{1}$ See for example, IMF (2004), Cottareli (2003),
} 
believe, interesting new insights into the working of EMU, it clearly could be improved on in various ways and we hope our work will spur such further research. Therefore throughout the text, we indicate potential ways in which such improvements can be made. The outline of the reminder of the paper is as follows. The next section sets the scene with a description of the new neoclassical synthesis modeling framework. Section 3 presents our discussion of the NSS framework in the context of a monetary union - this section is central to the policy conclusions of the paper. Section 4 concludes and indicates avenues for further research

\section{A Sketch of the New Neoclassical Synthesis Model ${ }^{2}$}

In this section we discuss some of the key features of the benchmark new neoclassical synthesis model of Goodfriend (2002). The model incorporates classical features, such as a real business cycle (RBC) component, and Keynesian features, such as monopolistically competitive firms with sticky prices. In particular, the model behaves like the flexible price RBC model on average, but with some possibility for deviations of actual output from potential output in the short run, and thus some room for monetary policy to influence aggregate demand and stabilize employment and inflation. Since the basic structure of this class of model is now well known, we focus on certain key relationships which are relevant to the key objectives of our paper, leaving a complete account of the model to the appendix.

\section{1. The flexible price variant}

The model is set up for a single country, $i$, and the representative household maximizes consumption subject to a standard budget constraint. With a log utility consumption function, the households' utility from lifetime consumption is maximized (that is, the optimal consumption plan is obtained), when the marginal rate of substitution is equal to the marginal rate of transformation:

\footnotetext{
${ }^{2}$ See Goodfriend (2002).
} 
$\left(1+\rho_{i}\right) \frac{c_{2}^{i}}{c_{1}^{i}}=\left(1+r_{i}\right)$

where $c_{l}$ and $c_{2}$ represent the marginal utility from consumption in periods 1 and 2 , respectively, $r$ is the real interest rate and $\rho_{i}$ is the subjective discount or time-preference factor (see the appendix for a full discussion).

The household allocates time between leisure and work and the household gets direct utility from leisure and indirectly from earning a wage and using the wage to buy consumption goods ${ }^{3}$. Assuming log utility functions for leisure and consumption it can be demonstrated that the household's willingness to supply labor is a function of household consumption and the real wage:

$n_{i}^{s}=1-\frac{c_{i}}{w_{i}}$

where $n^{s}$ denotes labour supply and $w$ is the real wage.

In each country there are assumed to be a large number of monopolistically competitive firms so that each firm can sustain a price above the marginal cost of production. Firms adjust their prices to maintain the profit maximizing markup of price over marginal cost, $\mu^{*}$, at all times and the profit maximizing markup is invariant to shifts in demand or in the cost of production. With a Cobb Douglas production technology it can be demonstrated that the first order condition for the firm is:

$\mu_{i}=\frac{a_{i}}{w_{i}}$

where $(1 / a)$ is the hours of work needed to produce one unit of consumption, $w$ is the real wage $(W / P)$. From expression 3), the equilibrium real wage, $w^{*}$, is determined as:

$$
w_{i}^{*}=\frac{a_{i}}{\mu_{i}^{*}}
$$

\footnotetext{
${ }^{3}$ The hourly wage buys $w$ units of consumption and the household values the additional w units of consumption at $u^{\prime}(c)=1 / c$. So, the household ears $w / c$ units of utility by working an hour instead of taking leisure.
} 
Furthermore, the equilibrium employment, $n^{*}$, and the equilibrium output, $c^{*}$, in each country can be shown to be determined as:

$$
\begin{aligned}
& n_{i}^{*}=\frac{1}{1+\mu_{i}^{*}}, \\
& c_{i}^{*}=a \frac{1}{1+\mu^{*}},
\end{aligned}
$$

Thus, the equilibrium employment $n^{*}$, in the flexible price RBC model depends only on the profit maximizing markup $\mu^{*}$ and does not fluctuate with productivity, $a^{4}$, whereas output, $c^{*}$, grows and fluctuates proportionally with productivity $a$. By substituting the current and future supply of consumption goods $\left(c_{1} * c_{2} *\right)$ into the optimal lifetime consumption plan 1) an expression for the equilibrium interest rate may be obtained as:

$$
1+r_{i}^{*}=\left(1+\rho_{i}\right) \frac{a_{2}^{i} \frac{1}{1+\mu_{i}^{*}}}{a_{1}^{i} \frac{1}{1+\mu_{i}^{*}}}=\left(1+\rho_{i}\right) \frac{a_{2}^{i}}{a_{1}^{i}} .
$$

From expression 7) we see that the real equilibrium interest rate varies directly with the growth of labor productivity, as in standard neoclassical growth theory models. The driving force for this is the existence of the life time consumption plan and the consumption smoothing of a representative agent. For example, when future productivity is expected to be higher than current productivity $\left(a_{1}<a_{2}\right)$, households will want to borrow against their brighter future income prospects to bring some consumption forward in time. As they smooth consumption and borrow against the future, households drive up the real interest rate to the point where they are satisfied with the steeply sloped consumption plan that matches the growth of productivity. Hence, the real equilibrium interest rate clears the economy-wide goods market by inducing the representative household to spend exactly

\footnotetext{
${ }^{4}$ The reason is that productivity $a$ affects consumption $c$ and the real wage $w$ proportionally given hours worked $n$.
} 
the amount of its current income; demand matches supply and the economy is in equilibrium with stable inflation.

\subsection{The NNS with sticky prices}

Relaxing the assumption that firms constantly adjust prices to maintain the profit maximizing markup, allows aggregate demand to generate short-term fluctuations in employment and output. In the presence of menu costs, it is costly for a firm to change its product price. Consequently, a firm decides to change the price of its product to restore the profit maximizing markup only when demand or cost conditions move the actual markup persistently away from the profit maximizing markup. If a firm expects the shock to the markup to be temporary it will not change its price to restore the profit maximizing markup. Given this behaviour, we can write the following inflation function:

$\pi=I N F\left(\mu_{1}, E \mu_{2}\right)+E \pi$

where $E \pi$ is the expected rate of inflation, and $\operatorname{INF}\left(\mu_{1}, E \mu_{2}\right)$ is a function indicating the effect of the current and expected future markup on inflation. When the current and expected future markup are equal, the profit maximizing markup is zero, $\operatorname{INF}\left(\mu^{*}, \mu^{*}\right)=0$, and firms move their prices in accordance with expected inflation, $E \pi$, as in the flex-price variant of the model. Markup compression $\left(\mu<\mu^{*}\right)$ moves actual inflation above expected inflation whereas markup expansion $\left(\mu>\mu^{*}\right)$ moves actual inflation below expected inflation.

Stickiness of prices means that current employment and output are determined by the aggregate demand for goods. This outcome is central to the new neoclassical synthesis: although firms maintain the profit maximizing markup on average over time, so that the NSS model behaves like the flexible price RBC model on average, there is nonetheless some scope for monetary policy to influence aggregate demand and stabilize employment and inflation in the short-run. 


\subsection{The central bank reaction function}

The central bank's policy actions may be described in the following way, for one of the countries. The central bank implements monetary policy a short-term target interest rate, $\bar{R}$ For simplicity we assume that expected inflation $E(\pi)=0$, and the central bank's nominal interest rate target, $\bar{R}$, translates into a certain target for the real interest rate, $\bar{r}$. Furthermore, the public expects future markups to be at their profit maximizing level, $E\left(\mu_{2}\right)=\mu^{*}$, and current and future productivity $\left(a_{1}, a_{2}\right)$ are given by technology and independently of interest policy, so that from 6) expected future household consumption $c_{2}{ }^{*}=a_{2} \frac{1}{1+\mu^{*}}$. Hence, using equation 1), we can write the effect of a change in the central bank's interest rate target $\bar{R}=\bar{r}$ on current consumption as: $c_{1}=\frac{1+\rho}{1+\bar{r}} * a_{2} \frac{1}{1+\mu^{*}}$

Expression 9) reveals the way interest rate policy influences aggregate demand: current consumption $c_{1}$ is inversely related to the real interest rate target, $\bar{r}$, when expected future consumption is anchored at $a_{2} \frac{1}{1+\mu^{*}}$. An increase in the real interest rate target depresses current aggregate demand by raising the opportunity cost of current consumption in terms of future consumption. The contraction in aggregate demand is reflected, in turn, in reduced current employment, $n_{1}$, a low current real wage, $w_{1}$, and an expanded current markup $\mu_{1}$. Conversely, a cut in the real interest rate target expands current aggregate demand, raises the real wage, and compresses the markup. 


\subsection{An example of catching-up and the role of central bank}

In this section we consider an example of catching-up, in terms of a shift in trend productivity growth, ${ }^{5}$ in the context of the NNS model and, in particular, consider the central banks reaction to this shock. With such a shock, current and future productivity are related by $a_{2}=(1+g) a_{1}$, where $g$ is the trend growth rate and current productivity, $a_{1}$, is taken as given. Assuming that the interest rate policy is expected to keep the actual markup at the profit maximizing markup in the future, $\mu_{2}=\mu^{*}$, future income prospects will vary directly with the growth rate, $g$ :

$$
y_{2}=(1+g) a_{1} \frac{1}{1+\mu^{*}} .
$$

Using conditions A2) and A3) and setting $y_{1}=c_{1}$ (current income is demand determined when prices are sticky), we can solve for current aggregate consumption, $c_{1}$, in terms of future income $y_{2}$ and the central bank's real interest rate target, $\bar{r}$ :

$c_{1}=\frac{1+\rho}{1+\bar{r}} \cdot y_{2}$.

By substituting $y_{2}$ from 10) into 11) we see that - holding $\bar{r}$ constant - a household transmits higher future income induced by an increase in trend productivity growth to current consumption, employment and output. In other words, households smooth consumption by borrowing in the credit market as they want to allocate any expected change in lifetime resources to both current and future consumption.

From this example we see that a positive shock to trend productivity growth is inflationary: an increase in current aggregate demand raises the real wage and compresses the markup due to an increased demand for labor. However, the central bank can stabilize the economy by moving its real interest rate target proportionately with the growth rate, $g$ (and thus real equilibrium interest rate, 
$r^{*}$; substitute $(1+g) a_{1}$ for $a_{2}$ in 7$)$. The higher real interest rate target gives households an incentive not to consume expected resources prematurely. In other words, in order to stabilize the economy the central bank has to "cut off" consumption smoothing by raising its real interest rate target, $\bar{r}$. This result will be central to our subsequent policy analysis.

\section{An interpretation of the NNS model in the context of a monetary union}

Now consider the case where country $i$ decides to form a monetary union with country $j$, where the two countries establish a common central bank that is responsible for the price stability in the whole currency area and uses a short term interest rate as its monetary policy instrument ${ }^{6}$. The representative agent in country $j$ faces a similar maximizing problem to that considered in the last section.

The lifetime budget constraint for the whole currency area is composed of a weighed average of the budget constraints of the household from country $i$ and $j$.

$\left.C_{2}=\alpha\left[-\left(1+r_{i}\right) C_{1}^{i}+\left(1+r_{i}\right)\left(y_{1}^{i}+\frac{y_{2}^{i}}{\left(1+r_{i}\right)}\right)\right]+(1-\alpha)\left[-\left(1+r_{j}\right) C_{1}^{j}+\left(1+r_{j}\right)\left(y_{1}^{j}+\frac{y_{2}^{j}}{\left(1+r_{j}\right)}\right)\right], 12\right)$

where the parameter $\alpha$ denotes the share of country-i' household's lifetime budget constraint in that of the whole currency area. For concreteness, $\alpha$ represents $i$-country's economic size, measured by its share in the GDP of the whole monetary area.

In the monetary union, monetary policy is set by a central monetary authority, a common central bank, whose sole objective is to stabilize a certain weighted average inflation rate for the whole currency area (in the context of the euro area this would be the HICP). The common central bank implements monetary policy using a nominal short-term interest rate policy instrument

\footnotetext{
${ }^{5}$ Although it is possible to use the NSS to analyse a variety of shocks, in this paper we focus only on productivity shocks, as they are the most relevant for our purposes. For more details see Goodfriend (2002).

${ }^{6}$ In what follows we assume that when the two countries form the monetary union the combined economic area is closed. This is clearly unrealistic and means we ignore other reasons for inflation differentials in a monetary union, such as those which stem from having a common external exchange rate (see, for example, Honohan and Lane (2003)). However, our approach does help to highlight what we believe is the key source of inflation differentials in EMU.
} 
(nominal interest rate target) which translates directly into a certain target of a weighted average real interest rate (for the whole currency area) that is consistent with the price stability objective of the central bank (currency area-wide inflation rate). Note, however, that - exactly as in EMU individual country inflation rates, and therefore actual real long-term interest rates, may differ across the two countries. The nominal interest rate target is, in turn, equal for all member countries. Member countries' real equilibrium long-term interest rates are then determined by the productivity growth path in each country, as in equation 7). The nominal interest rate target is set according to a response function of the common central bank, where the change of the interest rate instrument is a weighted average of the change in equilibrium interest rates in both countries.

\section{1. Homogenous monetary union and productivity shocks}

In this section we consider the impact of productivity shocks in the context of a homogeneous, or symmetrical, monetary union. A homogeneous monetary union is one in which both Member States of the monetary union are exactly the same in terms of the parameters of their economies, in particular in terms of their productivity growth rates in period 1 and 2 . Thus, both countries face exactly the same equilibrium interest rate, $\left(1+r_{i}^{*}\right)=\left(1+r_{j}^{*}\right)$. The target real interest rate $\bar{r}$ for the monetary union that is consistent with the stability objective of the common central bank is now a weighted average of each individual country's real equilibrium interest rates $\left(1+r_{i}^{*}\right)$ and $\left(1+r_{j}^{*}\right)$ and we can think of this as the reaction function of the common central bank:

$$
(1+\bar{r})=\alpha\left(1+r_{i}^{*}\right)+(1-\alpha)\left(1+r_{j}^{*}\right)
$$

where again, $\alpha$, represents the $i$ country's economic size in terms of its share of the GDP of the whole currency area. 
As in the single country example given above, we assume that the central bank has control over the common weighted average real interest rate $\bar{r}$ via its (common) instrument nominal interest rate $\bar{R}$, so that

$$
\bar{r}=\bar{R} \text {. }
$$

Before proceeding further it is important to explain the relationship between the interest rates, $\left(r_{i}^{*}, r_{j}^{*}\right),\left(r_{i}, r_{j}\right), \bar{r}$ and $\bar{R} . \bar{R}$ is the nominal short-term interest rate policy instrument (nominal interest rate target) used by the common central bank to implement monetary policy. In the monetary union, the nominal interest rate target is, of course, equal for all member countries. The nominal interest target translates directly into, $\bar{r}$, i.e. a target real interest rate (for the whole currency area) that is consistent with the price stability objective of the central bank (currency areawide inflation rate). Specifically, $\bar{r}$, is a weighted average of equilibrium interest rates in both countries (with weights being the shares of each country in the GDP of the whole currency area). Importantly, $\bar{r}$ stabilizes the currency area as a whole but not necessarily each individual member country. Furthermore, $\left(r_{i}^{*}, r_{j}^{*}\right)$ are the member countries' real equilibrium long-term interest rates that are country specific and are determined by the productivity growth paths in each country. From 13) we see that if the share of country $j$ is very small, $(1-\alpha) \rightarrow 0$, the $j$ th country cannot influence the common real interest rate and this is consistent with the standard assumption that a small open economy cannot influence the world interest rate. Finally, $\left(r_{i}, r_{j}\right)$ are the actual real long-term interest rates in each country. Exactly as in EMU, they may differ across member states, due, for example, to the existence of a risk premium, e.g. default risk $^{7}$ (as well as due to differences in individual country inflation rates). For concreteness, with inflation given, we can write that:

$r_{i}=r+\sigma_{i}$,

\footnotetext{
${ }^{7}$ We assume that that fixing of the bilateral exchange rates within the monetary union is fully credible, there is not exchange rate risk.
} 
$r_{j}=r+\sigma_{j}$

where $\sigma$ is a default risk term which is assumed to be a function of debt-to-GDP ratio, $\delta$, such that $\sigma=\phi(\delta)$

where the default risk is an increasing function of $\delta$, so that $\phi^{\prime}(\delta)>0$.

Importantly, from 13) we can also see that - abstracting from default risk - $\bar{r}$ can diverge from $r_{i}^{*}$ or $r_{j}^{*}$, the interest rates required to preserve economic stability in a given country - this constitutes the fundamental challenge for the common monetary policy of the whole currency area. Only if the productivity path is exactly the same in both countries, i.e. $r_{i}^{*}=r_{j}^{*}$, is the common real interest rate target exactly at the level that both countries would need, and $\bar{r}=r_{i}^{*}=r_{j}^{*}$.

Given the above, and as long as both countries creating the monetary union are exactly the same in terms of productivity in both periods (as well as time preference $\rho$ ), the real interest target would coincide with the interest rates that both countries would face had they not formed the monetary union. Also, if both countries are hit by a symmetric productivity shock such as the one analyzed in section 2 , the central bank reaction will be the same as if the monetary union were a single country and the nominal interest rate target $\bar{R}$ will have to be increased proportionately to the increase in the productivity growth rate. However, executing monetary policy in a heterogeneous monetary union is more complicated, as we now demonstrate.

\subsection{Heterogeneous monetary union and productivity shocks: implications for inflation differentials and credit booms}

A heterogeneous monetary union has two aspects: differences in growth rates and differences in economic size between the members of the union. It is important to note that stabilization issues arise only when both conditions are not met simultaneously. For example, if growth rates in both member countries are exactly the same, the monetary union behaves like a symmetric union and no stabilization issues arise - the economic size of the countries does not 
15

matter in this situation. The latter condition is thus necessary but not sufficient for heterogeneity being a potentially complicating factor in the conduct of monetary policy in the currency area.

In this paper we consider a heterogeneous monetary union in a form that very much resembles EMU. The union consists of two countries, a big "core" country and a small "periphery" country. The "core" country is a productivity laggard, whereas the "periphery" is a catching-up country, with high trend productivity growth rate. To study this case we first assume that $\alpha>(1-\alpha)$, so that economic size of country $i$ is "bigger" than that of country $j$. For concreteness, we assume that $\alpha$ is substantially higher than $(1-\alpha)$, namely 0.99 . In other words the "core" country represents $99 \%$ of the whole common currency area and the periphery country accounts for only $1 \%$ of the whole area, in terms of their economic size. Although clearly this is not a very good description of existing intra-European links in EMU, it is a good description of the size of the current group of new EU Member States vis a vis the Euro area (in terms of their GDP levels).

Given these weights, it follows from 13) and 14) that $\bar{r}=\bar{R}$ reacts much more heavily to changes in the productivity path in country $i$ than in country $j$. For all practical purposes country $j$ is "forced" to accept the changes in the interest $\bar{r}=\bar{R}$ that are due to changes in economic conditions in country $i$.

For example, assume now that country $j$ starts to catch-up, i.e. there is an increase, $g$, in trend productivity in the small country, $j$. Had the country $j$ not participated in the monetary union, its central bank would have to increase the interest rate by $g$; that is, in proportion to the increase in the growth rate. In a monetary union, however, equations 13) and 14) indicate that the common central bank would raise its interest rate target by only $(1-\alpha) g$, which is less than the amount $(g)$ required to stabilize the economy of country $j$. The common monetary policy therefore fails to respond to the productivity shock in the smaller country ${ }^{8}$.

\footnotetext{
${ }^{8}$ Note that the above discussion does not mean that prior to monetary union the central bank tries to promote optimal consumption smoothing, whereas following monetary union, it pursues price stability. In both cases, price stability is
} 
As a result of this, something akin to a boom-bust cycle may therefore potentially develop in the catching-up country, $j$. For example, in the "boom-phase", households in the catching-up country borrow in the credit market to smooth consumption and actual output deviates from its potential, employment and wages rise and the actual mark-up is persistently squeezed below the profit maximizing mark-up. If this situation persists, firms in the catching-up country will eventually start adjusting their mark-ups upwards to the profit maximizing level, stimulating additional inflation ${ }^{9}$. The inflation differential for the monetary union rises and the real interest rate in the catching-up country falls (hence, the gap between the actual real interest rate and the equilibrium interest rates widens even further). In this case, however, the positive inflation differential in the catching-up country is not an equilibrium adjustment of relative prices as is usually presumed in the Balassa-Samuelson framework, but rather a result of demand pressure driven by consumption smoothing stimulated by the positive productivity shock. Obviously, the degree of the inflation differentials between the two countries will depend on the extent to which the law of one price holds. In a small and very open economy the inflation differentials may be negligible, whereas in a more closed economy, these differentials might be significant. Irrespective of the CPI inflation effect, one would expect an increase in the asset price inflation that would fuel the boom through the wealth effect. Finally, the structure of the economy will also determine the extent to which the demand pressure arising from the consumption smoothing will spill-over onto the trade or current account balance.

In the "bust-phase", household's borrowing for consumption smoothing eventually increases the debt-to-GDP ratio (additionally, if part of the demand is spent on imports the current account position may deteriorate). By virtue of 16), rising debt of the private sector increases the country's

\footnotetext{
the primary objective - promoting optimal consumption smoothing is just the way of achieving this objective in a onecountry case. In a situation of heterogeneous countries who form a monetary union, the common central bank is not in a position to achieve optimal consumption smoothing in both countries at the same time, although it can achieve the price stability objective for the whole area. The basic point is therefore that while centralized monetary policy works well from the perspective of area wide average inflation, it might not be optimal for certain member states.

${ }^{9}$ For this result to hold, there has to be some deviation from PPP.
} 
default risk, $\delta$, and thus the real interest rate starts to increase too. This, in turn, leads to both an increase of the costs of debt service and a slowdown of GDP growth. Eventually, interest rates will rise (and so will the comparative price level) sufficiently to restore equilibrium but it may come at a cost of a potential recession or underperformance in the medium-term. The extent of this effect will, of course, depend on the degree of flexibility of product and labour markets in a given country.

It is crucial to stress that in the above discussion it is implicitly assumed that agents do not have perfect foresight. Of course, in the absence of uncertainty the default risk would not rise and the country could afford to borrow given the increase in productivity. Departure from this assumption is thus necessary for our result to hold. Suppose consumers in the catch-up country expect higher productivity and start borrowing against future income. But if - as we suggest in the paper - the one-size-fits-all policy entails interest rates which are too low and, as a consequence, produce a misallocation of resources, and hence; leads to lower then expected future income in a catch-up country, the bust will follow. In this real-world case solvability or sustainability issues arises and these will be incorporated into the default risk.

\subsection{The Balassa-Samuelson effect - an extra "kick"}

So far we have assumed an economy-wide productivity shock in country $j$ that caused divergence in the trend productivity growth between the two countries. However, much of the traditional discussion of productivity shocks focuses on their sectoral impact. In particular, the standard Balassa-Samuelson effect (BS effect) relates to the effects of differences in trend productivity growth between traded and nontraded sectors and between countries. We now add in a standard BS effect into our version of the NSS model.

We assume that the two economies produce traded and nontraded goods using the same Cobb-Douglas production technology:

$y_{t}=a_{t} n_{t}^{\beta} k_{t}^{1-\beta}$ 
$y_{n}=a_{n} n_{n}^{\gamma} k_{n}^{1-\gamma}$

where the terms have the same definition as before, subscripts $t$ and $n$, denote the traded and nontraded sectors and $\beta$ and $\gamma$ indicate the shares of labor in each sector.

As in the traditional BS account, we assume that the law of one price holds for tradables (so that the price of tradables $P_{t}$ is equal to one) and the real wage in that sector is determined by the marginal product of labor:

$W_{t}=\beta a_{t}\left(\frac{k_{t}}{n_{n}}\right)^{1-\beta}$

Since labor is mobile between the traded and non-traded sectors, the real wage is equalized across sectors as:

$W=W_{t}=\frac{W_{n}}{P_{n}}=\gamma a_{t}\left(\frac{k_{t}}{n_{n}}\right)^{1-\gamma}$.

With these assumptions it is then straightforward to demonstrate that a positive shock to total factor productivity in the traded sector raises the average wage in the economy, the relative price of nontraded to traded goods rises, and the CPI-based real exchange rate appreciates. Hence we have the standard Balassa-Samuelson prediction that there should be a positive (negative) relationship between total factor productivity in the traded (nontraded) sector and the CPI-based real exchange rate. To see this, assume for simplicity that the sectoral elasticities, $\beta$ and $\gamma$, are equal. From the above it follows that the relative price, $P=P_{n} / P_{t}$, is determined by relative productivities between the traded and nontraded sector:

$p=p_{n}-p_{t}=\frac{\gamma}{\beta} a_{t}-a_{n}$

Dynamically, a higher productivity growth rate in the traded relative to the non-traded sector has - ceteris paribus - an inflationary effect; assuming the law of one price holds, with the tradable prices constant, an increase in the relative price of non-tradable to traded goods raises the overall 
price level. This productivity-driven inflation rate is usually regarded as an equilibrium phenomenon, since it simply reflects the normal adjustment of relative prices to productivity changes and does not therefore have an adverse effect on either internal or external macroeconomic stability.

What consequence does the BS effect have for our analysis of stabilization policy in a heterogeneous monetary union in the context of the NSS framework? To answer this question assume that the economy wide productivity shock, $a$, is a weighted average of sectoral productivities, so that:

$$
a=\theta a_{t}+(1-\theta) a_{n}
$$

where $\theta$ is a share of the traded sector in the economy.

Consider now the case where country $j$ experiences a higher trend productivity growth in its traded sector relative to its nontraded sector so that, as before, the economy-wide trend productivity growth increases by $g$. By virtue of 13) and 14), the common central bank raises the interest rate target $\bar{R}$ by only $(1-\alpha) g$, which is less than that required to stabilize the economy $j$. However, since the increase of $a$ stems from an increase in the trend productivity growth in the traded sector, $a_{t}$, country $j$ experiences an additional BS effect-driven inflation pressure: according to 20) an increase in relative productivity growth causes relative prices to rise. Higher inflation means that the actual real interest rate falls even more and - importantly - departs even further from the equilibrium interest rate that would be required to stabilize the economy given by expression 7). So the BS effect introduces an "extra kick" into the fall in the real interest rate that is generated in the base-line version of the NSS model and this creates the kind of demand pressures discussed above. In sum the BS effect has two components in our variant of the NSS model: the standard equilibrium productivity-driven component and a demand-side, consumption-smoothing, component. The former is an equilibrium phenomenon whereas the latter is viewed as an out-of-equilibrium 
phenomenon: from a competitiveness perspective, country j's comparative price level increases and its competitiveness suffers.

\section{Conclusions}

In this paper we have proposed an alternative explanation of the nature, sources and consequences of inflation rate differentials in a monetary union, such as the EMU. In doing so, we have built on the new neoclassical synthesis framework, which has recently been advanced by Goodfriend (2002) and Goodfriend and King (2000). In general terms, we demonstrate that the divergent inflation rates between member states of a monetary union do not necessarily have to be an equilibrium phenomenon, even if the original shock comes from the supply-side of the economy. We identify consumption-smoothing as the channel for this phenomenon.

The key message in our paper is that with a one-size-fits-all monetary policy, the current group of new EU member states may face a bumpy ride towards full monetary integration with the EMU. In particular, we have demonstrated, in the context of an optimizing model, that productivity shocks are likely to have a much less benign effect on inflation differentials within the Euro area than would be expected on the basis of the traditional Balassa-Samuelson model. This is because in a heterogeneous monetary union - one in which the GDP of the catch-up countries is only a small proportion of the euro area - the one-size-fits-all monetary policy will fail to respond to the productivity growth in the catching up countries thereby imparting an extra layer of demand side inflation. The latter, in turn, may create a credit boom which has unpleasant consequences for asset price inflation, the debt/GDP ratio in the catch-up countries and also for their unemployment and growth rates. The tendency for inflationary differentials to arise in heterogenous monetary unions with catch-up, is likely to be exacerbated if there are sectoral productivity differences within the 'catch-up' countries.

Although we have not formally modeled them in our paper, our results highlight the importance of other policies, such as fiscal policies and financial market prudential regulation 
policies, in ensuring the smooth functioning of a heterogeneous monetary union, such as EMU. This seems particularly important for the new EU Member States whose desire for full integration with the euro area is combined with the prospect of a fast catching-up process and a need for further financial deepening of their economies. The link between these policies and the monetary policy in a monetary union with catch-up, , would appear to be an important subject for further research perhaps using the framework proposed in this paper.

Given the rudimentary nature of our analysis, our paper should be regarded as a first step in using the NNS to analyse monetary unions. In particular, the NNS could be developed in a twocountry framework open economy setting, thereby allowing for other sources of inflationary differentials. Allowance also for departures from PPP and Fisher equations would also enrich the analysis by allowing the mark-up to deviate from its optimal level. Likewise, a formal introduction of uncertainty would allow a more systematic analysis of the boom-bust scenario we discuss in the paper.

\section{References:}

Balassa, Bela. (1964). “The Purchasing Power Parity Doctrine: A Reappraisal.” Journal of Political Economy (December): 584-596.

Bergin Paul, Reuven Glick and Alan M. Taylor. (2004). "Productivity, Tradability, and the Long-Run Price Puzzle”, NBER Working Paper 10569, June.

Bergstrand, J. H. (1991). 'Structural determinants of real exchange rates and national price levels: Some empirical evidence', American Economic Review, pp. 325-34.

Canzoneri, M.B., R.E. Cumby and B. Diba. (1996). Trends in European productivity and Real exchange Rates: Implications for the Maastricht Convergence Criterion and for Inflaton Targets after EMU, CEPR Discussion Paper No 1417.

Carlo Cottarelli, Giovanni Dell'Ariccia, and Ivanna Vladkova-Hollar. (2003). Early Birds, Late Risers, and Sleeping Beauties: Bank Credit Growth to the Private Sector in Central and Eastern Europe and the Balkans, IMF Working Paper WP/03/213 
De Gregorio, José, Alberto Giovannini and Holger Wolf. (1994). International Evidence on Tradables and Nontradables Inflation. European Economic Review 38: 1225-1244.

Dornbusch, R. (1988). 'Purchasing power parity'. In Eatwell, J., Milgate, M. and Newman, P. (eds.), The New Palgrave Dictionary of Economics, London: Macmillan, pp. 1075-85.

Froot, K.A. and Rogoff, K. (1995). Perspectives on PPP and long-run exchange rates, pp. 1648-

1688 in Grossman, G. M. and Rogoff, K. (eds), Handbook of International Economics, Vol. III, New York, Elsevier

Goodfriend, M. and Robert King. (2001). “Case for Price Stability", NBER Working Paper 8423.

Goodfriend, M. (2002). Monetary Policy in the New Neoclassical Synthesis: A Primer, Federal Reserve Bank of Richmond, July.

Gottfries Nils. (2003). Boom and Busts in EMU, Uppsala University Economics Working Paper No. 2003-29.

Honohan Patrick and Philip R. Lane (2003), "Divergent inflation rates in EMU," Economic Policy 37: 359-94.

IMF. (2004). "Are Credit Booms in Emerging Markets a Concern? In: World Economic Outlook: Advancing Structural Reforms, IMF, Washington D.C., April.

Neary, J. P. (1988). 'Determinants of the equilibrium real exchange rate', American Economic Review, 78, pp. 210-15.

Samuelson, Paul. (1964). Theoretical Notes on Trade Problems. Review of Economics and Statistics (46) (May): 145-154.

Podkaminer Leon. (2003). Analytical Notes on the Balassa-Samuelson Effect. Banca Nazionale de Lavoro Quarterly Review, No. 226, pp. 207-221. 


\section{Appendix}

\section{The New Neoclassical Synthesis Approach: Household and Firm Behaviour.}

In this appendix we present the derivation of the key household and firm equilibrium conditions contained in the text. Since the model is symmetric with respect to the home and foreign country we focus here only on the household and firm in country $i$.

\section{Household consumption}

Each country contains a representative household which maximizes lifetime utility, $U\left(C_{1}, C_{2}\right)$, which depends on period consumption levels, $C$ :

$U^{i}\left(C_{1}^{i}, C_{2}^{i}\right)=U\left(C_{1}^{i}\right)+\frac{1}{1+\rho_{i}} U^{i}\left(C_{2}^{i}\right)$

where $U\left(C_{1}^{i}\right)$ represent utility from consumption in the present period, $U\left(C_{2}^{i}\right)$ is utility from future consumption, $\rho_{i}$ is a fixed preference parameter, the subjective discount or time-preference factors and $U^{i}\left(C_{1}^{i}, C_{2}^{i}\right)$ is therefore the present discounted values of lifetime utility from consumption. The parameters are positive, and measure consumers' impatience to consume. In other words, consumers favor current consumption over future consumption. As usual, we assume that the period utility function $U(C)$ is strictly increasing in consumption and strictly concave: $U^{`}(C)>0$ and $U^{\prime \prime}(C)<0$.

The lifetime budget constraint of each household is given by:

$C_{2}^{i}=-\left(1+r_{i}\right) C_{1}^{i}+\left(1+r_{i}\right)\left(y_{1}^{i}+\frac{y_{2}^{i}}{\left(1+r_{i}\right)}\right)$

where $y$ is output (which is assumed perishable and cannot be stored for later consumption), $y_{1}^{i}+\frac{y_{2}^{i}}{\left(1+r_{i}\right)}$ is the present discounted value of lifetime income prospects of a representative household from the country $i$, and $\left(1+r_{i}\right)$ represents the "marginal rate of transformation" of future for current consumption. Equation (A2) says that the household's lifetime consumption cannot exceed their lifetime income.

Assuming the utility function has a $\log$ form, $U(C)=\log c$, so that $U^{\prime}(C)=1 / c$, each household's marginal rate of substitution, is given by:

$$
\frac{d C_{2}^{i}}{d C_{1}^{i}}=-\left(1+\rho_{i}\right) \frac{C_{2}^{i}}{C_{1}^{i}}
$$


Equation A3) says that the household values current consumption more highly relative to future consumption the more abundant is planned future consumption compared to planned current consumption.

The households' utility from lifetime consumption is maximized, i.e. the optimal consumption plan is obtained, when the marginal rate of substitution is equal to the marginal rate of transformation:

$$
\left(1+\rho_{i}\right) \frac{c_{2}^{i}}{c_{1}^{i}}=\left(1+r_{i}\right)
$$

\section{Household Labor supply}

Each household's time budget supply is given by:

$l_{i}+n_{i}=1$,

where, $l$ is time allocated to leisure and $n$ is time allocated to work by each household; the amount of time per period is normalized to 1 . A household gets direct utility from leisure and indirectly by earning a wage and using the wage to buy consumption goods ${ }^{10}$.

Assuming log utility functions for leisure and consumption, the allocation of time in a given period which maximizes the household's utility is that where the marginal utility earned directly from leisure equals the marginal utility earned indirectly by working:

$\frac{1}{l_{i}}=\frac{w_{i}}{c_{i}}$

Given A5) and A6), household's willingness to supply labor is a function of household consumption and the real wage:

$$
n_{i}^{s}=1-\frac{c_{i}}{w_{i}}
$$

\section{Firms, Employment and Output}

In each country there are a large number of monopolistically competitive firms; i.e. each firm is large in its market but small with respect to the whole economy. Firms can sustain a price above the marginal cost of production and adjust their prices to maintain the profit maximizing markup of price over marginal cost, $\mu^{*}$, at all times. The profit maximizing markup is invariant to shifts in demand or in the cost of production.

\footnotetext{
${ }^{10}$ The hourly wage buys $w$ units of consumption and the household values the additional $\mathrm{w}$ units of consumption at $u^{\prime}(c)=1 / c$. So, the household earns $w / c$ units of utility by working an hour instead of taking leisure.
} 
The production function has a standard Cobb-Douglas form:

$y=a n^{\beta} k^{1-\beta}$,

where $y$ denotes output, and $a, n$ and $k$ stand for productivity, labor and capital. For simplicity we assume constant returns to scale and constant capital stock. Furthermore, noting that total output is fully consumed, we can write production of consumption goods $c$ in each country as being generated by using only labor input, $n$, according to the following, linear, production technology:

$c_{i}=a_{i} n_{i}$,

where $a_{i}$ denotes labor productivity in units of consumption goods produced per hour in each country. Labor productivity fluctuates and grows over time with technological progress.

In each country the firm's markup of price over its marginal cost of production is given by $\mu_{i}=\frac{P_{i}}{M C_{i}}$

where $\mathrm{P}$ is the price of a unit of consumption goods, and $\mathrm{MC}$ is the marginal $\operatorname{cost}^{11}$.

Given that $M C$ is equal to the nominal wage, $W$ times (1/a) hours of work needed to produce one unit of consumption, equation A10) can be rearranged as:

$\mu_{i}=\frac{a_{i}}{w_{i}}$

where $w$ is the real wage $(W / P)$.

If we define the equilibrium real wage as $w^{*}$ it follows from (A11) in each country is determined as: $w_{i}^{*}=\frac{a_{i}}{\mu_{i}^{*}}$

where real wage grows and fluctuates directly with productivity

Equilibrium employment in each country, $n^{*}$, is determined by using A9) and A12) to substitute for $c$ and $w$ in the labor supply function A8). From this we obtain the desired labor supply $n^{s}$ in each country as:

$n_{i}^{s}=1-\frac{a_{i} n_{i}}{a / \mu_{i}^{*}}$,

and equate it to labor utilized by each country's firm $n,\left(n^{s}=n\right)$,

\footnotetext{
${ }^{11}$ Note, although this is not crucial for the end results, that $P_{i}$ and $P_{j}$ may or may not be necessarily equal in participating countries.
} 
$n_{i}^{*}=\frac{1}{1+\mu_{i}^{*}}$

Equilibrium output $c^{*}$ in each country is determined from production technology A9) and equilibrium employment A14) as:

$c_{i}^{*}=a \frac{1}{1+\mu^{*}}$,

where output $c^{*}$ grows and fluctuates proportionally with productivity $a$. 


\title{
CESifo Working Paper Series
}

\author{
(for full list see www.cesifo-group.de)
}

1697 Helge Berger, Optimal Central Bank Design: Benchmarks for the ECB, March 2006

1698 Vjollca Sadiraj, Jan Tuinstra and Frans van Winden, On the Size of the Winning Set in the Presence of Interest Groups, April 2006

1699 Martin Gassebner, Michael Lamla and Jan-Egbert Sturm, Economic, Demographic and Political Determinants of Pollution Reassessed: A Sensitivity Analysis, April 2006

1700 Louis N. Christofides and Amy Chen Peng, Major Provisions of Labour Contracts and their Theoretical Coherence, April 2006

1701 Christian Groth, Karl-Josef Koch and Thomas M. Steger, Rethinking the Concept of Long-Run Economic Growth, April 2006

1702 Dirk Schindler and Guttorm Schjelderup, Company Tax Reform in Europe and its Effect on Collusive Behavior, April 2006

1703 Françoise Forges and Enrico Minelli, Afriat's Theorem for General Budget Sets, April 2006

1704 M. Hashem Pesaran, Ron P. Smith, Takashi Yamagata and Liudmyla Hvozdyk, Pairwise Tests of Purchasing Power Parity Using Aggregate and Disaggregate Price Measures, April 2006

1705 Piero Gottardi and Felix Kubler, Social Security and Risk Sharing, April 2006

1706 Giacomo Corneo and Christina M. Fong, What's the Monetary Value of Distributive Justice?, April 2006

1707 Andreas Knabe, Ronnie Schoeb and Joachim Weimann, Marginal Employment Subsidization: A New Concept and a Reappraisal, April 2006

1708 Hans-Werner Sinn, The Pathological Export Boom and the Bazaar Effect - How to Solve the German Puzzle, April 2006

1709 Helge Berger and Stephan Danninger, The Employment Effects of Labor and Product Markets Deregulation and their Implications for Structural Reform, May 2006

1710 Michael Ehrmann and Marcel Fratzscher, Global Financial Transmission of Monetary Policy Shocks, May 2006

1711 Carsten Eckel and Hartmut Egger, Wage Bargaining and Multinational Firms in General Equilibrium, May 2006 
1712 Mathias Hoffmann, Proprietary Income, Entrepreneurial Risk, and the Predictability of U.S. Stock Returns, May 2006

1713 Marc-Andreas Muendler and Sascha O. Becker, Margins of Multinational Labor Substitution, May 2006

1714 Surajeet Chakravarty and W. Bentley MacLeod, Construction Contracts (or "How to Get the Right Building at the Right Price?”), May 2006

1715 David Encaoua and Yassine Lefouili, Choosing Intellectual Protection: Imitation, Patent Strength and Licensing, May 2006

1716 Chris van Klaveren, Bernard van Praag and Henriette Maassen van den Brink, Empirical Estimation Results of a Collective Household Time Allocation Model, May 2006

1717 Paul De Grauwe and Agnieszka Markiewicz, Learning to Forecast the Exchange Rate: Two Competing Approaches, May 2006

1718 Sijbren Cnossen, Tobacco Taxation in the European Union, May 2006

1719 Marcel Gérard and Fernando Ruiz, Interjurisdictional Competition for Higher Education and Firms, May 2006

1720 Ronald McKinnon and Gunther Schnabl, China's Exchange Rate and International Adjustment in Wages, Prices, and Interest Rates: Japan Déjà Vu?, May 2006

1721 Paolo M. Panteghini, The Capital Structure of Multinational Companies under Tax Competition, May 2006

1722 Johannes Becker, Clemens Fuest and Thomas Hemmelgarn, Corporate Tax Reform and Foreign Direct Investment in Germany - Evidence from Firm-Level Data, May 2006

1723 Christian Kleiber, Martin Sexauer and Klaus Waelde, Bequests, Taxation and the Distribution of Wealth in a General Equilibrium Model, May 2006

1724 Axel Dreher and Jan-Egbert Sturm, Do IMF and World Bank Influence Voting in the UN General Assembly?, May 2006

1725 Swapan K. Bhattacharya and Biswa N. Bhattacharyay, Prospects of Regional Cooperation in Trade, Investment and Finance in Asia: An Empirical Analysis on BIMSTEC Countries and Japan, May 2006

1726 Philippe Choné and Laurent Linnemer, Assessing Horizontal Mergers under Uncertain Efficiency Gains, May 2006

1727 Daniel Houser and Thomas Stratmann, Selling Favors in the Lab: Experiments on Campaign Finance Reform, May 2006 
1728 E. Maarten Bosker, Steven Brakman, Harry Garretsen and Marc Schramm, A Century of Shocks: The Evolution of the German City Size Distribution 1925 - 1999, May 2006

1729 Clive Bell and Hans Gersbach, Growth and Enduring Epidemic Diseases, May 2006

1730 W. Bentley MacLeod, Reputations, Relationships and the Enforcement of Incomplete Contracts, May 2006

1731 Jan K. Brueckner and Ricardo Flores-Fillol, Airline Schedule Competition: ProductQuality Choice in a Duopoly Model, May 2006

1732 Kerstin Bernoth and Guntram B. Wolff, Fool the Markets? Creative Accounting, Fiscal Transparency and Sovereign Risk Premia, May 2006

1733 Emmanuelle Auriol and Pierre M. Picard, Government Outsourcing: Public Contracting with Private Monopoly, May 2006

1734 Guglielmo Maria Caporale and Luis A. Gil-Alana, Modelling Structural Breaks in the US, UK and Japanese Unemployment Rates, May 2006

1735 Emily J. Blanchard, Reevaluating the Role of Trade Agreements: Does Investment Globalization Make the WTO Obsolete?, May 2006

1736 Per Engström and Bertil Holmlund, Tax Evasion and Self-Employment in a High-Tax Country: Evidence from Sweden, May 2006

1737 Erkki Koskela and Mikko Puhakka, Cycles and Indeterminacy in Overlapping Generations Economies with Stone-Geary Preferences, May 2006

1738 Saku Aura and Thomas Davidoff, Supply Constraints and Housing Prices, May 2006

1739 Balázs Égert and Ronald MacDonald, Monetary Transmission Mechanism in Transition Economies: Surveying the Surveyable, June 2006

1740 Ben J. Heijdra and Ward E. Romp, Ageing and Growth in the Small Open Economy, June 2006

1741 Robert Fenge and Volker Meier, Subsidies for Wages and Infrastructure: How to Restrain Undesired Immigration, June 2006

1742 Robert S. Chirinko and Debdulal Mallick, The Elasticity of Derived Demand, Factor Substitution and Product Demand: Corrections to Hicks' Formula and Marshall's Four Rules, June 2006

1743 Harry P. Bowen, Haris Munandar and Jean-Marie Viaene, Evidence and Implications of Zipf's Law for Integrated Economies, June 2006

1744 Markku Lanne and Helmut Luetkepohl, Identifying Monetary Policy Shocks via Changes in Volatility, June 2006 
1745 Timo Trimborn, Karl-Josef Koch and Thomas M. Steger, Multi-Dimensional Transitional Dynamics: A Simple Numberical Procedure, June 2006

1746 Vivek H. Dehejia and Yiagadeesen Samy, Labor Standards and Economic Integration in the European Union: An Empirical Analysis, June 2006

1747 Carlo Altavilla and Paul De Grauwe, Forecasting and Combining Competing Models of Exchange Rate Determination, June 2006

1748 Olaf Posch and Klaus Waelde, Natural Volatility, Welfare and Taxation, June 2006

1749 Christian Holzner, Volker Meier and Martin Werding, Workfare, Monitoring, and Efficiency Wages, June 2006

1750 Steven Brakman, Harry Garretsen and Charles van Marrewijk, Agglomeration and Aid, June 2006

1751 Robert Fenge and Jakob von Weizsäcker, Mixing Bismarck and Child Pension Systems: An Optimum Taxation Approach, June 2006

1752 Helge Berger and Michael Neugart, Labor Courts, Nomination Bias, and Unemployment in Germany, June 2006

1753 Chris van Klaveren, Bernard van Praag and Henriette Maassen van den Brink, A Collective Household Model of Time Allocation - a Comparison of Native Dutch and Immigrant Households in the Netherlands, June 2006

1754 Marko Koethenbuerger, Ex-Post Redistribution in a Federation: Implications for Corrective Policy, July 2006

1755 Axel Dreher, Jan-Egbert Sturm and Heinrich Ursprung, The Impact of Globalization on the Composition of Government Expenditures: Evidence from Panel Data, July 2006

1756 Richard Schmidtke, Private Provision of a Complementary Public Good, July 2006

1757 J. Atsu Amegashie, Intentions and Social Interactions, July 2006

1758 Alessandro Balestrino, Tax Avoidance, Endogenous Social Norms, and the Comparison Income Effect, July 2006

1759 Øystein Thøgersen, Intergenerational Risk Sharing by Means of Pay-as-you-go Programs - an Investigation of Alternative Mechanisms, July 2006

1760 Pascalis Raimondos-Møller and Alan D. Woodland, Steepest Ascent Tariff Reforms, July 2006

1761 Ronald MacDonald and Cezary Wojcik, Catching-up, Inflation Differentials and Credit Booms in a Heterogeneous Monetary Union: Some Implications for EMU and new EU Member States, July 2006 